\title{
E-BOOK CERITA BERGAMBAR PENCEGAHAN BULLYING UNTUK ANAK USIA 9-11 TAHUN BERBASIS ALKITAB
}

\author{
Eka Anggraeni Krisdian*, Iman Subekti \\ Program Studi Pendidikan Guru Sekolah Dasar, Universitas Kristen Petra \\ Jl. Siwalankerto 121-131, Surabaya \\ E-mail: "g11170021@ john.petra.ac.id; ${ }^{2}$ imansubekti@petra.ac.id \\ *Penulis korespondensi
}

\begin{abstract}
ABSTRAK
Cables News Network (CNN) Indonesia (Desember 2019), mencatat 41\% pelajar Indonesia mengaku menjadi korban bullying / perundungan. Sedangkan, rata-rata anak dalam perundungan pada negara OCED (Organisation of Economic Co-operation and Development) sebesar 23\%. Indonesia juga menjadi negara urutan ke-5 dari 78 negara yang memiliki jumlah kasus perundungan murid terbanyak. Fenomena terjadinya bullying oleh anak-anak ini juga terjadi di Sekolah Kristen yang menerapkan Pendidikan Kristen. Fenomena ini terjadi dalam komunitas anak usia 9-11 tahun. Komunitas Pendidikan Kristen yaitu keluarga, sekolah, dan gereja harus segera bertindak untuk melakukan pencegahan terhadap tindakan bullying yang tidak sesuai dengan teladan dan kasih Tuhan Yesus Kristus. Pencegahan dapat dilakukan dengan berbagai cara misalnya program literasi digital yaitu $e$ book cerita bergambar yang dekat dengan dunia anak-anak. Perspektif Alkitab haruslah menjadi dasar atas perancangan dari pencegahan bullying dengan tepat. E-book cerita bergambar pencegahan bullying untuk anak usia 9-11 tahun berbasis Alkitab bertujuan untuk memberikan edukasi mengenai pengertian, dampak, dan jenis dari bullying serta memberikan pandangan dari Alkitab (konsep Creation, Fall, Redemption, Consummation) yang dipakai sebagai prinsip pencegahan bullying. E-book ini dibuat melalui tahap perencanaan cover, isi, grafis dan pemilihan bahasa. Hasil validasi menujukkan bahwa produk ini layak untuk digunakan dengan adanya masukan dari validator ahli. Analisis uji coba yang dilakukan adalah dengan menggunakan wawancara dan angket kuesioner. Hasil dari uji coba menunjukkan bahwa melalui e-book ini, anak usia 9-11 tahun mengalami peningkatan pengetahuan mengenai bullying dan memahami konsep CFRC sebagai prinsip pencegahan bullying.
\end{abstract}

Kata kunci: Alkitab Bullying, Pencegahan, Usia 9-11 tahun.

\section{ABSTRACT}

Cables News Network (CNN) Indonesia (December 2019), noted that 41 percent of Indonesian students admit to being victims of bullying. Meanwhile, the average child bullied in the OCED (Organization of Economic Co-operation and Development) 
country is 23 percent. Indonesia is the fifth country out of 78 countries with the highest number of student bullying cases. The phenomenon of bullying by children also occurs in Christian schools that implement Christian education. This phenomenon occurs in the community of children aged 9-11 years. The Christian Education Community, namely families, schools, and churches, must act immediately to design the prevention of bullying that is not in accordance with the example of the love of the Lord Jesus Christ. Prevention can be done through various things, for example digital literacy programs, namely e-books with pictorial stories that are close to the world of children. The biblical perspective must form the basis of the design of bullying prevention appropriately. E-book about bullying prevention stories for children aged 9-11 years based on the Bible aims to provide education about the meaning, impact, and types of bullying as well as provide a view from the Bible (the CFRC concept) which is used as the principle of preventing bullying. This e-book was created through the stages of cover planning, content, graphics and language selection. The results of the validation show that this product is suitable for use with input from expert validators. The trial analysis carried out is by using an interview and a questionnaire. The results of the trial show that through this e-book, children aged 9-11 years have increased knowledge of bullying and understand the concept of CFRC as the principle of bullying prevention.

\section{Keywords: Bible, Bullying, Prevention, , 9-11 years old.}

\section{PENDAHULUAN}

Menurut pemberitaan laman Cables News Network (CNN) Indonesia (Desember 2019), tercatat $41 \%$ pelajar Indonesia mengaku menjadi korban bullying atau perundungan. Sedangkan, rata-rata anak dalam perundungan pada negara OCED (Organisation of Economic Cooperation and Development) sebesar $23 \%$. Selain itu, Indonesia menjadi negara urutan ke 5 dari 78 negara yang memiliki jumlah kasus perundungan murid terbanyak. Dapat berbentuk kekerasan fisik, dikucilkan, kepunyaannya dicuri, diintimidasi, diancam, didorong, dan juga pengalaman buruknya disebarkan. (Jayani, 2018) Menurut observasi penulis sebelumnya, didapatkan sebuah fenomena bullying pada anak usia 9 tahun yang masih terjadi pada komunitas yang menjalankan pendidikan Kristen. Dalam hal ini, menerima pengucilan dari teman komunitasnya ketika lambat dalam menerima pembelajaran.

Markus 12:31 menyatakan bahwa kita sebagai anak-Nya diberi tanggung jawab untuk mengasihi sesama manusia. Rasul Paulus juga menuliskan pada 1 Korintus 13:4-8 mengenai sifat-sifat kasih yang sabar, tidak kasar, tidak bersukacita atas ketidakadilan dan tidak mencari keuntungan pada diri sendiri. Tentu saja tindakan bullying tidak sesuai dengan teladan yang diberikan Tuhan Yesus Kristus.

Hal ini jelas harus mendapat perhatian khusus berupa pencegahan dari komunitas Kristen yang menjalankan Pendidikan Kristen dan semua kalangan. Pencegahan yang dilakukan pada tindakan bullying bisa beragam kepada anak-anak. Namun dalam masa pandemi seperti sekarang ini, murid akan jarang bertemu dengan guru dan lebih banyak belajar dari rumah. Menurut Badan Siber dan Sandi (2020), meskipun tindakan bullying tidak bisa terjadi secara langsung, tetapi hal-hal tersebut bisa saja muncul melalui teknologi yang biasa digunakan oleh mereka seperti televisi dan gadget.

Perkembangan teknologi, informasi dan 
komunikasi yang semakin maju, memiliki peran tersendiri bagi dunia pendidikan. Direktur Jenderal Aplikasi Informatika Bambang Heru Tjahjono (2016, dalam Ibnu) menyatakan bahwa ada sekitar 80100 juta pengguna internet atau media digital. Angka ini merupakan angka kenaikan dari riset sebelumnya yang dilakukan oleh UNICEF (2014) yang menyatakan didapati sejumlah 30 juta anak dan remaja di Indonesia menjadi pengguna internet atau media digital.

Berbagai pembelajaran mulai menggunakan teknologi modern sebagai sumber belajar ataupun alat bantu pembelajaran. Dalam pembelajaran, anak-anak juga dibekali keterampilan dalam penggunaan teknologi dan semacamnya. Menurut Riyanto (2011, dalam Syawaludin, 2019) dengan adanya perkembangan teknologi, informasi, dan komunikasi dapat memudahkan dalam pembelajaran, salah satunya dalam mengakses bahan ajar elektronik. Bahan ajar elektronik yang dimaksudkan adalah buku digital atau sering disebut e-book. Penggunaan $e$-book tentu tidak juga digunakan untuk bahan ajar saja. Buku digital dapat digunakan untuk media penyampaian informasi dan pengetahuan yang lain. Dalam hal ini, penulis membuat sebuah $e$-book cerita bergambar untuk pencegahan bullying pada anak 9-11 tahun.

Hal ini dikarenakan masa pandemi yang mengharuskan anak untuk tetap di rumah dan belajar melalui daring. Penulis berharap orangtua dapat ikut mengawasi anak dalam penyampaian pesan kepada anak. Tidak hanya itu, penulis berharap e-book ini juga dapat menghibur anak-anak selama proses belajar di rumah agar anak tidak bosan. Diharapkan anak belajar mengenai pengertian, jenis, pandangan Kristen dan dampak dari bullying, setelah membaca $e$-book tersebut.

\section{BULLYING}

Bullying adalah tindakan yang dilakukan seseorang atau kelompok yang lebih kuat terhadap seseorang atau kelompok yang lain yang dapat mengakibatkan luka baik fisik maupun psikis.

Menurut Ken Rigby, bullying adalah sebuah keinginan seseorang atau kelompok yang lebih kuat, dilakukan secara berulang dan menyakiti seseorang ataupun kelompok lain untuk kesenangan diri sendiri (2007, dalam Astuti 2008).

Menurut Priyatna (2010), bullying juga bisa disebut sebagai "tindakan yang sengaja dilakukan oleh si korbannya. Tindakan itu terjadi berulang. Bullying tidak pernah dilakukan secara acak atau cuma sekali saja dan didasari perbedaan power yang mencolok..." Bullying dapat diartikan sebagai tindakan yang sengaja dilakukan oleh seorang atau sekelompok orang yang lebih kuat secara fisik, kekuasaan dan kemampuan untuk menyakiti seorang atau sekelompok orang secara berulang baik secara fisik, psikologis, sosial, atau pun verbal.

Dalam Alkitab, tindakan bullying saat itu lebih dikenal sebagai tindakan penindasan. Habakuk 2:6 mengatakan, "Bukankah sekalian itu akan melontarkan peribahasa mengatai dia, dan nyanyian olok-olok serta sindiran ini: Celakalah orang yang menggaruk bagi dirinya apa yang bukan miliknya--berapa lama lagi? --dan yang memuati dirinya dengan barang gadaian." Dalam perikop ayat tersebut tertulis, "Penghukuman atas para penindas." Bentuk bullying menurut ayat tersebut yaitu, mengolok, mengatai, menyindir, dan merampas hak yang bukan miliknya. Pengkhotbah 4:1 menyatakan bahwa penindasan dilakukan oleh orang-orang yang memiliki kekuasan sebagai berikut, "Lagi aku melihat segala penindasan yang terjadi di bawah matahari, dan lihatlah, air 
mata orang-orang yang ditindas dan tak ada yang menghibur mereka, karena di pihak orang-orang yang menindas ada kekuasaan." Namun, hal tersebut sama sekali bukan teladan Tuhan Yesus Kristus. Begitu besar kasih-Nya hingga dia harus datang ke dalam dunia untuk menyelamatkan dunia dari penindasan dosa.

Menurut Coloroso (2007, dalam Zakiyah, Humaedi \& Santoso, 2017) bullying dapat dikelompokkan dalam 4 jenis yaitu :

1. Bullying Fisik, contohnya yaitu menendang, memukul, mendorong, menampar, menjegal, meludahi.

2. Bullying Verbal, contohnya mengolok-olok, mengancam, menghina, memaki, membentak, fitnah, menyebar gosip.

3. Bullying Relasional salah satu bentuknya yaitu pengucilan, penyingkiran, dan penghindaran.

4. Cyber bullying adalah tindakan bullying yang dilakukan melalui media digital ataupun sosial media. Misalnya menguploud gambar dengan ujaran kebencian yang ditujukan kepada orang tertentu.

Dalam tindakan bullying, terdapat 3 peran yang terlibat di dalamnya (Coloroso, 2003) yaitu the Bully atau pelaku bully), the Bullied atau korban bully, dan The Bystander(s) atau penonton tindakan bully.

Priyatna (2010) menyebutkan bahwa bullying dapat terjadi karena banyak faktor, di antaranya adalah pola asuh orangtua terhadap anak, pergaulan anak, penanganan sekolah terhadap tindak bullying yang kurang tegas, karakteristik perbedaan komunitas, dan perbedaan gender.

Coloroso (2006) menyampaikan bahwa bullying akan berpengaruh terhadap kemampuan prestasi akademik dan juga cenderung korban akan lebih menarik diri dari komunitas sosialnya. Tidak hanya itu, dampak bullying bagi korban adalah kesehatan mental terganggu atau muncul trauma (Modecki, Minchin, Harbaugh, Guerra, \& Runions, 2014, dalam Darmayanti, Kurniawati, Biondi, 2019). Dampak bullying yang sangat dikhawatirkan ketika korban mengalami depresi hingga memilih untuk mengakhiri hidupnya.

Kustiyono (2020) menyatakan bahwa dampak yang terjadi jika pelaku tidak diberikan pendisiplinan dan pemulihan adalah anak akan toleransi dan pro pada kekerasan yang terjadi di sekitarnya.

Dampak untuk bystanders atau penonton adalah pemikiran bahwa bullying adalah hal yang wajar dan saling melukai adalah hal yang biasa dan dapat mengalami kecemasan Pencegahan bullying adalah hal yang sangat penting dilakukan sebelum tindakan bullying semakin bertambah. Bullying dapat dicegah apabila anak sadar akan adanya dampak yang negatif setelah kejadian tersebut terjadi. Kurangnya pemahaman anak-anak mengenai bullying juga berpengaruh pada meningkatnya kasus bullying di lingkungan sekolah.(Nandya, Putra \& Komariah, 2017)

Menurut Janita dan Prasanti (dalam Prasanti \& Kristiani, 2018) mengatakan bahwa pencegahan bullying dapat dilakukan oleh keluarga dengan cara mengupayakan komunikasi dengan anak-anak. Hal ini bertujuan agar keluarga dapat mengetahui apa yang menjadi masalah mereka di dalam lingkungan sekolah atau rumah.

Media cerita bergambar dapat digunakan sebagai media untuk mengedukasi anakanak dan orang tua mengenai pengertian dan dampak bullying (Nandya, Putra \& Komariah, 2017). Sebuah penelitian ketika cerita tersebut juga dibawakan dengan menceritakannya atau story telling, hal tersebut juga dapat memberikan stimulus kepada anak untuk berpikir kritis 
menyelesaikan masalah dari contoh cerita yang dibawakan. (Ikaningrum, IndriyanI, Fortinasari, Dewi \& Diani 2020).

Sumber bacaan literasi digital dapat digunakan sebagai solusi mengatasi masalah sosial, salah satunya yaitu perundungan. (Kemendikbud, 2017) Maka dari itu, penulis menciptakan sebuah e-book untuk memberikan edukasi kepada anak-anak mengenai bullying. Sehingga, kesadaran yang muncul akan merubah pola pikir anak-anak mengenai bullying.

\section{CERITA BERGAMBAR}

Menurut Huck, Helper dan Hickman (1987, dalam Nurgiyantoro 2018) mengemukakan bahwa sastra anak, termasuk cerita anak, menghadirkan sebuah cerita dan imajinasi dari sudut pandang anak. Nurginyantoro (2018, p. 8) juga memberikan pandangannya bahwa cerita anak dalam kisahnya harus diceritakan berdasarkan sudut pandang anak-anak dalam menggunakan atau memperlakukan sesuatu dan disesuaikan dalam pemahaman emosi dan pikiran anak.

Menurut Zulela (2012) langkahlangkah dalam menulis cerita anak adalah menentukan Tema (gambaran besar cerita), tokoh, plot atau alur cerita, penggunaan gaya bahasa, dan pengembangan cerita ke dalam isi cerita sesuai dengan jenis cerita yang dipilih. (dalam Risna, 2017)

Cerita anak dibagi dalam 2 jenis cerita, yaitu prosa fiksi dan prosa non fiksi. Menurut Supriyadi (2006), Cerita prosa fiksi anak dibagi dalam berbagai bentuk salah satunya yaitu cerita bergambar, (dalam Risna, 2017, p. 31)

Cerita bergambar adalah cerita yang di dalamnya terdapat gambar dan kata yang saling bergantung menjadi kesatuan cerita (Mitchel 2008, dalam
Adipta, Mayaherni, Hasanah. 2016). Media cerita bergambar dibuat dengan memadukan sebuah teks dan gambar yang sedemikian rupa untuk menjadi satu kesatuan (Salamah, 2017).

Banyak manfaat yang didapatkan dari cerita bergambar. Cerita bergambar dapat digunakan sebagai media penyampaian komunikasi dan menambah wawasan. Selain itu, cerita yang disajikan dalam cerita bergambar juga dapat melatih anak untuk memecahkan masalah yang ada dalam kehidupan sehari-hari. Menurut Knoeller (1994, dalam Hasanah. n.d.), cerita anak bermanfaat untuk perkembangan sosial, emosi dan intelektual anak. Menurut Madyawati (2016), manfaat dari cerita untuk anak yaitu, pembentukan moral dan pribadi anak, media untuk anak menyalurkan kebutuhan imajinasi dan fantasi. Gambargambar yang ada pada cerita anak akan memberi stimulus otak anak untuk berimajinasi, dan memberikan stimulus kemampuan verbal anak. Anak tidak hanya harus memperhatikan bacaannya saja, namun mereka juga membaca, memahami pola kalimat dan menambah perbendaharaan kosa kata baru.

\section{E-BOOK}

Menurut Syawaludin (2019), E-book atau Elektronic book adalah sebuah bentuk buku yang dapat dibuka melalui media elektronik seperti laptop, gadget, tablet, dan computer. E-book adalah bentuk lain dari sebuah buku cetak Buku cetak terdiri dari beberapa lembaran kertas, namun e-book dirancang dalam bentuk digital tanpa kertas.

E-book ini adalah salah satu inovasi yang dapat digunakan sebagai media belajar. (Syawaludin,501). Penyampaian informasi jauh lebih mudah karena dapat disalurkan melalui media sosial, website, kelas maya, email dan media digital lainnya tanpa dikirim secara fisik dan mudah dibawa kemana pun.

E-book dapat berasal dari buku cetak yang 
dipindai dan diubah bentuk dan format agar dapat dibaca secara digital. Namun, ada juga yang langsung dibuat sendiri dengan menggunakan aplikasi tertentu. Pengguna $e$-book tidak hanya dari kalangan orang dewasa. Anak-anak juga dapat menggunakan e-book dengan pengawasan orang dewasa dalam hal ini orangtua, guru, wali murid.

\section{PERKEMBANGAN ANAK USIA 9-11 TAHUN}

Menurut Piaget (dalam Slavin, 2008) anak pada usia ini memasuki tahap operasional konkret. Dalam tahap ini, anak dapat menyimpulkan makna dari apa yang mereka lihat dan amati. Hal penting yang dipelajari dalam tahap usia ini adalah pengurutan. penyusunan dan sistematika logis.

Menurut Meumen (n.d.) masa pengamatan anak pada usia ini memasuki masa analisis. Pada masa analisis, anak dapat membedakan sifat-sifat dan bagian-bagiannya serta pengamatannya nyata. (dalam Adinda, Ilham \& Dianto, n.d)

Perkembangan sosial anak dikemukakan oleh Erikson bahwa pada usia ini, pergaulan sosial semakin luas dikarenakan adanya pergaulan dalam sekolah (Slavin, 2008). Dalam usia 9-11 tahun, anak memasuki tahap industry dan inferiority. Dalam tahap ini, anak mengenal sebuah lingkungan sosial yang luas, mendapat umpan balik dan evaluasi dari teman merupakan bentuk penerimaan untuknya. (Sarayati, 2016)

Pada usia 9-11 tahun anak sudah mulai berfikir logis, namun mereka masih perlu dijelaskan mengenai iman mereka kepada Tuhan agar mereka memahami dan mengerti bahwa Tuhan yang menjawab pergumulan. Pada masa ini, anak perlu mengenal konsep Tuhan yang nyata, Tuhan yang selalu ada, Tuhan hadir dalam 3 Pribadi, Tuhan Yesus adalah 100\% Allah dan $100 \%$ manusia, tidak ada hal yang terjadi di luar kehendak Tuhan, dan Allah itu baik (Primasanti, 2019).

\section{PERSPEKTIF KRISTEN}

Allah adalah pusat dari terbentuknya pendidikan Kristen yang terjadi di sekolah, keluarga, dan gereja. Douglos Wilson (dalam, Tety \& Wiraatmadja, 2017) menyatakan bahwa tujuan pendidikan Kristen, adalah suatu proses Tuhan menyediakan fasilitas pemulihan gambar dan rupa Allah yang rusak, sehingga dapat kembali dan memaknai dengan sungguhsungguh mengenai memenuhi mandat ciptaan-Nya dalam ketaatan kepada Firman Allah.

Biasanya, orang yang lebih dewasa cenderung mengatakan bahwa bullying itu bukan hal yang baik. Namun, anak-anak yang belum memahami tujuan Allah menciptakan manusia tentu memiliki banyak pertanyaan mengenai alasan mengapa hal tersebut tidak bisa untuk dilakukan. Maka dari itu, pengajar atau orang yang lebih dewasa dapat memberikan pemahamannya mengenai pandangan Kristen tentang hal tersebut.

Tuhan yang mengasihi kita sebagai anaknya, juga ingin melihat kita anak-Nya mengasihi Dia dan ciptaan yang lainnya. Markus 12:29-31 mengatakan, "29 Jawab Yesus: "Hukum yang terutama ialah: Dengarlah, hai orang Israel, Tuhan Allah kita, Tuhan itu esa. 30 Kasihilah Tuhan, Allahmu, dengan segenap hatimu dan dengan segenap jiwamu dan dengan segenap akal budimu dan dengan segenap kekuatanmu. 31 Dan hukum yang kedua ialah: Kasihilah sesamamu manusia seperti dirimu sendiri. Tidak ada hukum lain yang lebih utama dari pada kedua hukum ini."

Dalam 3 ayat tersebut, begitu jelas Tuhan ingin ciptaan-Nya mengasihi Dia. Ia juga 
menginginkan ciptaan-Nya mengasihi satu sama lain. Hal ini, tentu saja bertentangan dengan prinsip bullying yang cenderung tidak peduli, egois dan menyakiti. Dalam upaya pencegahan bullying, Tuhan mempersiapkan orangtua dan guru yang dekat dan berperan sebagai pendidik untuk anak-anak. Anak perlu memiliki pandangan yang benar mengenai tujuan Allah menciptakan manusia hingga pengorbanan Allah yang menjadi teladan bagi manusia untuk dapat menjalankan tujuan Allah tersebut.

Pengetahuan dan pemahaman akan realitas kita sebagai manusia dan realitas Tuhan sebagai Sang Pencipta dan Juru Selamat dipahami melalui konsep narasi Biblical Worldview. Dalam perancangan cerita ini, penulis akan mengintegrasikan narasi Bibblical Worldview yaitu Creation, Fall, Redemption, Consummation (CFRC) dalam penyampaian cerita.

\section{KONSEP CFRC (CREATION, FALL, REDEMPTION, CONSUMMATION)}

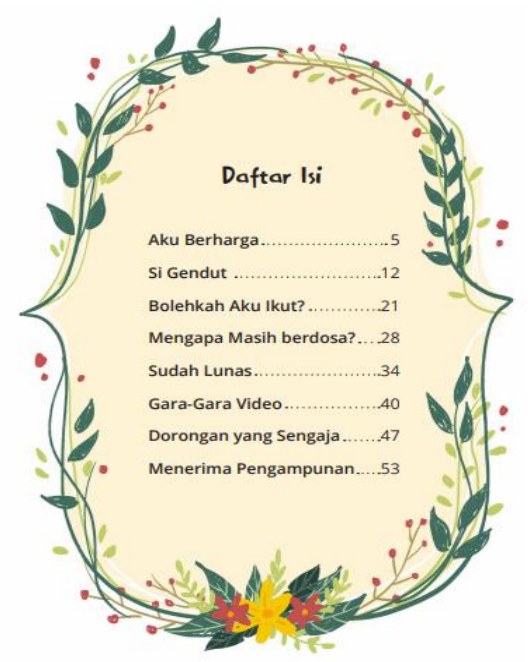

Gambar 1.1 Daftar Isi Buku

Creation adalah proses yang menjelaskan bahwa Allah menciptakan segala hal yang ada di bumi dan langit. Allah menciptakan manusia sesuai dengan gambar dan rupa Allah untuk menjaga alam semesta dan saling mengasihi satu sama lain (Direct Message for Parents, n.d.) Dalam konteks pencegahan bullying, pemahaman akan semua ciptaan Tuhan sangatlah baik dan berharga akan menolong anak untuk menghargai perbedaan satu sama lain. Pemahaman ini juga akan menolong anak bahwa dirinya adalah ciptaan yang teramat sangat berharga. Hal ini juga menolong anak menemukan keunikan dalam dirinya dan melatih kepercayaan diri. Ini dibawakan dengan beberapa cerita mengenai beberapa perbedaan yang terjadi dalam lingkungan keluarga dan lingkungan bermain serta sekolah.

Fall atau kejatuhan manusia ke dalam dosa dijabarkan dalam kitab Roma 3:23, "Karena semua orang telah berbuat dosa dan telah kehilangan kemuliaan Allah" Dalam konteks pencegahan bullying, pemahaman akan kejatuhan manusia dalam dosa disampaikan dengan tujuan untuk anak mengetahui dampak dari adanya tindakan bullying yang merupakan tindakan berdosa. Dengan itu anak dapat mengenal bahwa bullying adalah sebuah dosa. Dosa memberikan dampak yang buruk bagi kehidupan manusia.

Anak melatih diri untuk mengevaluasi sikap yang dilakukan terhadap orang lain dan meminta pengampunan kepada Tuhan. Ini sebagai bentuk berlatih untuk mengendalikan diri agar tetap menerapkan tindakan yang mencerminkan kasih. Ini dibawakan dengan beberapa cerita mengenai keberdosaan manusia membawa dampak buruk terhadap kehidupan manusia dan ketidakberdayaan manusia yang tetap berbuat dosa meskipun sudah belajar Kebenaran.

Ketidakberdayaan manusia berdosa menunjukkan manusia membutuhkan seorang penolong yang dapat menebus dosanya. Redemption merupakan narasi yang menggambarkan proses kedatangan seorang Juru Selamat yang merupakan Allah sendiri dalam rupa manusia. Penebusan dosa 
hingga sampai dengan saat ini bukan karena perbuatan baik dari manusia. Itu semua merupakan hal murni dari belas kasihan dan inisiatif Allah. ("Direct Message for Parents", n.d.) Dalam konteks pencegahan bullying, pemahaman akan penebusan yang dilakukan oleh Tuhan Yesus Kristus mengajarkan definisi kasih yang tulus. Pemahaman ini memberikan contoh kepada anak mengenai pengampunan yang harus dilakukan dalam tindakan bullying. Ini dibawakan dengan beberapa cerita mengenai kasus bullying yang memberikan dampak kesedihan mendalam, tetapi anak diajarkan untuk tetap mengampuni.

Consummation atau penyempurnaan yaitu keselamatan dan pengampunan yang diberikan oleh Allah melalui Yesus Kristus dan yang diterima oleh orang percaya akan memberikan dampak pada setiap perbuatan yang dilakukan. Karya keselamatan tersebut membawa pembaharuan terhadap segala ciptaan. Karya keselamatan memanggil kembali setiap orang yang percaya untuk hidup dalam kekudusan. Panggilan itu berupa tanggung jawab untuk menanti kedatangan Tuhan untuk memberikan kesempurnaan pada ciptaan yang baru. Dalam proses penantian, tindakan konkrit yang dapat dilakukan oleh anak-anak adalah menanti dengan sabar, berpengharapan, dan berpartisipasi dalam menyuarakan berita keselamatan. ("Direct Message for Parents”, n.d.) Dalam konteks pencegahan bullying, pemahaman mengenai penyempurnaan ditampilkan dengan penerapan tanggung jawab manusia selama menunggu kedatangan Tuhan. Pemahaman ini disammpaikan dengan memberikan contoh kepada anak mengenai pasrtisipasi yang perlu dilakukan untuk mengabarkan kebenaran terhadap orang lain. Ini dibawakan dengan beberapa cerita mengenai tindakan bullying yang berakhir dengan mengampuni sebagai bentuk partisipasi memberikan teladan kasih Kristus.

\section{PROSES PEMBUATAN PRODUK}

Sasaran dari perancangan ini adalah anakanak berusia 9-11 tahun. Sasaran dari cergam interaktif bertema bullying ini adalah :
a) Demografis
Umur : 9-11 tahun
Jenis kelamin : Laki-laki dan perempuan
Status sosial : Semua

Pendidikan : SD

Agama : Kristen

Etnik, Ras : Semua

Kebangsaan : Indonesia

b) Geografis : Surabaya-Sidoarjo, Indonesia

c) Psikografis : Netral, Pendiam, Mudah menangkap mudah berempati, mudah terpengaruh

\section{d) Behaviouristik: Suka membaca}

Bentuk produk cerita bergambar ini adalah berupa buku digital/ e-book. Format produk yang ini berupa Pdf. Ukuran yang digunakan untuk e-book adalah A4. Keseluruhan tampilan cerita bergambar dibuat berwarna untuk menarik perhatian pembaca agar tidak bosan serta dapat membuat pembaca lebih menikmati isi cerita.

Penulisan naskah yang digunakan dalam $e$ book cerita bergambar ini adalah deskriptif narasi. Naskah dari produk $e$-book cerita ini juga menampilkan beberapa percakapan dari tokoh-tokoh yang didesain. Pemilihan bahasa yang digunakan dalam cerita bergambar ini adalah bahasa Indonesia sederhana yang sering ditemui dalam kehidupan sehari-hari yang mudah dipahami oleh anak-anak. 
Gaya visual / Grafis yang digunakan untuk e-book cerita bergambar ini adalah kartun yang merupakan kesukaan dari anak-anak.

Dalam keefektifan mendayagunakan e-book tersebut, penulis membuat sebuah blog yang akan digunakan untuk menempatkan e-book agar dapat dengan mudah diakses oleh pembaca yang lain blog ini dibuat juga untuk penyampaian informasi kepada orang tua dan anak mengenai latar belakang pembuatan e-book, kasus-kasus bullying, pandangan Alkitab melalui bullying, dan tokoh Alkitab yang mengalami bullying, pengertian bullying, dampak bullying.

\section{CARA PENGGUNAAN PRODUK}

E-book ini ditujukan kepada semua anak yang pernah atau tidak pernah mengalami bullying. E-book ini bertujuan untuk memberikan pemahaman kepada anak usia 9-11 tahun mengenai bullying, dampak bullying, pandangan Alkitab tentang bullying dan cara mencegah bullying yang diintregasikan dengan Creation-Fall-Redemption-

Consumation.

Cara yang dilakukan dalam menggunakan e-book ini yaitu sebagai berikut :

1. Penulis akan membagikan $e$-book ini dalam bentuk link blog berikut ini

https://elishamencegahbullying.bl ogspot.com

2. Responden atau pembaca dapat membaca postingan pada halaman blog yang lain kemudian membuka halaman "Download" untuk mendapatkan $e$-book cerita bergambar.

3. Orangtua, guru, atau orang dewasa perlu mendampingi anak ketika anak sedang membaca buku. Ini bertujuan untuk memberikan stimulasi dan menolong anak memahami cerita yang dibaca dan juga membantu anak untuk memahami konsep dari biblical worldview.

4. Durasi membaca paling lama 30 menit. Hal ini bertujuan untuk menjaga kesehatan mata anak.

5. Setelah membaca keseluruhan buku, anak diberi kesempatan untuk merefleksikan dan menuliskan pengalamannya.

\section{UJI COBA PRODUK}

Tempat pelaksanaan uji coba dilakukan di tempat tinggal masing-masing anak. Tempat wawancara awal sebelum uji coba yaitu di tempat tinggal anak tersebut dan juga melalui aplikasi zoom meeting. Kemudian bertemu di dalam media untuk mengisi Kuesioner. Waktu pelaksanaan uji coba adalah 10 Desember 2020 sampai dengan 2 Januari 2021. E-book yang sudah selesai diberikan kepada dosen pembimbing sebagai validator pertama. Kemudian mendapatkan masukan dan penilaian melalui kuesioner. Setelah mendapat masukan dan penilaian, penulis melakukan proses wawancara kepada anak-anak untuk mengambil data awal mengenai pemahaman bullying, konsep Biblical worldview dan minat membaca. Setelah itu, memberikan $e$ book kepada validator kedua dan ketiga untuk diberi penilaian dan masukan. Kemudian penulis merevisi buku dan uji cobakan kepada anak-anak dan melakukan pengambilan refleksi.

\section{VALIDASI PRODUK}

E-book cerita bergambar pencegahan bullying untuk anak usia 9-11 tahun dianalisis dalam empat indikator, yaitu cover e-book, isi e-book, grafis, dan juga bahasa yang digunakan untuk e-book tersebut.

Sesuai dengan instrumen yang digunakan, pada indikator cover dengan bobot $10 \%$ 
terdapat 4 pernyataan, yaitu: (1) Judul yang menarik, (2) Gambar cover menyampaikan keseluruhan tema cerita, (3) Gambar cover menarik perhatian anak, (4) Gambar cover sesuai dengan dunia anak,

Pada indikator isi e-book dengan bobot $60 \%$ terdapat 12 pernyataan, yaitu: (1) Penyajian daftar isi pada buku, (2) Cerita yang disampaikan relevan dengan kehidupan anakanak, (3) Cerita menjelaskan konsep Creation, (4) Cerita menjelaskan konsep Fall, (5) Cerita menjelaskan konsep Redemption, (6) Cerita menjelaskan konsep Consummation, (7) Cerita menjelaskan pengetahuan bullying, (8) Cerita menjelaskan pencegahan bullying , (9) Isi buku mengarahkan anak untuk menyadari bullying adalah perbuatan yang salah , (10) Isi buku mengarahkan anak untuk tidak melakukan bullying , (11) Isi buku menolong anak untuk berefleksi, (12) Watak dari setiap tokoh disampaikan dengan jelas dan mudah dipahami.

Pada indikator grafis pada e-book terdapat 5 pernyataan, yaitu: (1) Gambar sesuai dengan isi cerita , (2) Gambar sesuai dengan usia anak , (3) Gambar menarik perhatian anak, (4) Ukuran gambar proporsional, (5) Posisi gambar sesuai dengan tata letak dalam tiap halaman, (6) Pemilihan warna pada tiap halaman menarik perhatian anak.

Pada indikator bahasa ada 4 pernyataan, yaitu: (1) Bahasa sesuai dengan tingkat perkembangan anak (anak usia 9-11 tahun), (2) Pemilihan fenis font, (3) Ukuran font yang digunakan, (4) Ketepatan tanda baca.

Setiap pernyataan pada indikator memiliki rentang skor dari $1-5$ dengan keterangan $1=$ tidak relevan/ tidak baik, 2 = kurang relevan/ kurang baik, $3=$ cukup relevan/ cukup baik, $4=$ relevan $/$ baik, $5=$ sangat relevan/ sangat baik. Dalam menentukan nilai pada validasi, skor maksimal untuk hasil validasi adalah 100 . Jadi system perhitungan yang digunakan adalah

$\frac{\text { Total nilai validasi yang didapatkan }}{\text { Total keseluruhan nilai validasi }} x$ bobot

Dari hasil uji keseluruhan nilai validitas terdapat empat kriteria kelayakan yang dikonversikan ke dalam bentuk angka, yaitu: (1) $81,0 \%-100,0 \%$ : sangat valid, dapat digunakan tanpa revisi, (2) 61,0\% - 80,9\%: Cukup valid, dapat digunakan namun perlu revisi, (3) 41,0 \% - 60,9 \%: Kurang valid, disarankan tidak digunakan karena perlu revisi besar. (4) $21,0 \%$ - 40,9 \%: Tidak valid, tidak boleh dipergunakan.

\section{HASIL \& ANALISIS UJI COBA PRODUK}

Dalam proses uji coba produk, tiga dari lima anak mengaku pernah menjadi korban bullying dan dua lainnya mengaku sebagai penonton bullying. Setelah 5 anak berusia 911 tahun membaca e-book berjudul "Elisha", kesimpulan yang didapatkan oleh penulis yaitu :

1. Anak yang lebih dulu mengalami bullying lebih mudah memahami pengertian dan dampak dari bullying.

2. Tantangan yang dihadapi penulis adalah keberagaman pemahaman mengenai konsep CFRC yang berbeda setiap anak. Hal ini mempengaruhi pola pikir anak memahami konsep CFRC.

3. Tantangan ini dapat terjawab dengan adanya orang tua/orang dewasa yang ikut mendampingi dan membimbing anak untuk memberikan stimulus kepada anak untuk memahami konsep CFRC yang terintegrasi dengan pengetahuan mengenai bullying. Namun, karena beberapa latar belakang keluarga dari anak-anak ini mayoritas bekerja, maka pendampingan orang tua tidak bisa dilakukan. Tetapi, penulis sebagai orang 
dewasa menggantikan pendampingan yang seharusnya dilakukan oleh orangtua. Hasilnya mulai terlihat adanya pemahaman konsep dengan bantuan pendampingan orangtua atau orang dewasa.

\section{DAFTAR REFERENSI}

41 persen siswa di indonesia pernah jadi korban bullying. (2019, December 05). Cables News Network Indonesia. Retrieved from

https://www.cnnindonesia.com/ gaya-hidup/20191205133925284-454419/41-persen-siswa-diindonesia-pernah-jadi-korbanbullying

Jayani. (2019, December 12). PISA: murid korban 'bully' di Indonesia tertinggi kelima di dunia. Databoks. Retrieved from https://databoks.katadata.co.id/d atapublish/2019/12/12/pisamurid-korban-bully-diindonesia-tertinggi-kelima-didunia

Kementrian Komunikasi dan Informatika Republik Indonesia. August 7 Anak-anak pengguna internet terus bertambah. Retrieved From https://kominfo.go.id/index.php/ content/detail/6744/Anak Anak+Pengguna+Internet+Teru $\underline{\text { s+Bertambah/0/sorotan_media }}$

Kementrian Komunikasi dan Informatika Republik Indonesia. Riset Kominfo dan UNICEF Mengenai Perilaku Anak dan Remaja Dalam Menggunakan Internet. Retrieved From https://kominfo.go.id/content/de tail/3834/siaran-pers-no17pihkominfo22014-tentangriset-kominfo-dan-unicef$\underline{\text { mengenai-perilaku-anak-dan- }}$ remaja-dalam-menggunakaninternet/0/siaran_pers

Syawaludin, M. (2019, January). Implementasi buku digital dalam mengoptimalkan pengunaan literasi untuk menyongsong revolusi industri 4.0 di dalam sekolah.. Prosiding Seminar Nasional Pendidikan Program Pascasarjana Universitas Pgri Palembagn. 499-508.

The Bully, The Bullied and The bystander: based on the work of Barbara Coloroso (2003). Retrieved August 30, 2020, from http://global.swlauriersb.qc.ca/english/ edservices/pedresources/bullying/bully .pdf

Priyatna, A. (2010). Let's end bullying: memahami, mencegah dan mengatasi bullying. Jakarta: PT. Alex Media Komputindo.

Zakiyah, E. Z,. Humaedi, S. \& Santoso, M. B. (2017, July). Faktor yang mempengaruhi remaja dalam melakukan bullying. Jurnal Penelitian dan PPM, 4(2). 129-389.

Kustiyono. (2019). Masalah dan pencegahan bullying pada anak sekolah. Retrieved August 30, 2020 from

https://osf.io/preprints/inarxiv/ec8na/

Astuti, P. R. (2008). Meredam bullying: 3 cara menanggulangi kekerasan pada anak. Jakarta: PT. Grasindo.

Darmayanti, K. K. H, Kurniawati, F \& Biondi, D. D. (2019). Bullying di sekolah : Pengertian, dampak, Pembagian dan cara menanggulangi. Pedagogia : Jurnal Ilmu Pendidikan, 17(1). Retrieved from https://ejournal.upi.edu/index.php/peda gogia/article/view/13980

Nurgiyantoro, B. (2018). Sastra anak: pengantar pemahaman dunia anak. Yogyakarta: Gadjah Mada University Press.

Adipta, H. Mayaherni, \& Hasanah. M. 
(2016). Pemanfaatan buku cerita bergambar sebagai sumber bacaan siswa sd. Jurnal Pendidikan: Teori, Penelitian, dan Pengembangan, 1(5), 989992. from http://journal.um.ac.id/index.ph p/jptpp/article/view/6337

Hasanah, M. (2012). Model cerita fiksi kontemporer anak-anak untuk pengembangan kemahirwacanaan siswa kelas 5 sekolah dasar. LITERA, 11(01), 98-109.

Risna. (2017). Pengembangan buku panduan menulis cerita anak bermuatan nilai karakter pada siswa kelas iii sd. Published undergraduate thesis, Universitas Negeri Semarang. Retrieved from https://lib.unnes.ac.id/30050/1/1 401413640.pdf

Salamah, E. R. (2017, February). Media cerita bergambar untuk meningkatkan keterampilan menulis puisi anak. Pedagogia : Jurnal Pendidikan, 6(01), 43-53. Retrieved from http://ojs.umsida.ac.id/index.ph p/pedagogia/article/view/616

Adinda, M. N. Ilham, C. W \& Dianto, F. (n.d). Periodesasi Masa Perkembangan Anak-Anak. Retrieved from https://core.ac.uk/download/pdf/ 151573488.pdf

Sarayati. (2016). Analisis faktor perilaku seksual pada anak sd di sdn dukuh kupang ii. Published undergraduate thesis, Universitas Airlangga. Retrieved from http://repository.unair.ac.id/296 $\underline{36 /}$

Primasanti, K. B. (2019). Grace-full child: menghadirkan anak-anak yang hidup dalam anugerah
Tuhan. Yogyakarta: Andi.

Tety \& Wiraatmadja, S. (2017). Prinsipprinsip filsafat pendidikan Kristen. Evangelikal: Jurnal Teologi Injili dan Pembinaan Warga Jemaat. Retrieved from

https://journal.sttsimpson.ac.id/index.p hp/EJTI/article/view/56/40

Ikaningrum, R. E. Indriyani, L. Fortinasari, P. B. Dewi, L. S. \& Diani, D. R. (2020). Pembiasaan Berpikir Kritis Menggunakan Teknik Storytelling untuk Menangkal Tindakan Bullying. Retrieved from. Jurnal Bahasa, 9(3), 38 , doi: https://doi.org/10.24114/kjb.v9i3.1996 $\underline{8}$

Direct Message for Parents. (n.d). Retrieved November 5, 2020, from https://dmparents.id/tanya-jawab/ 